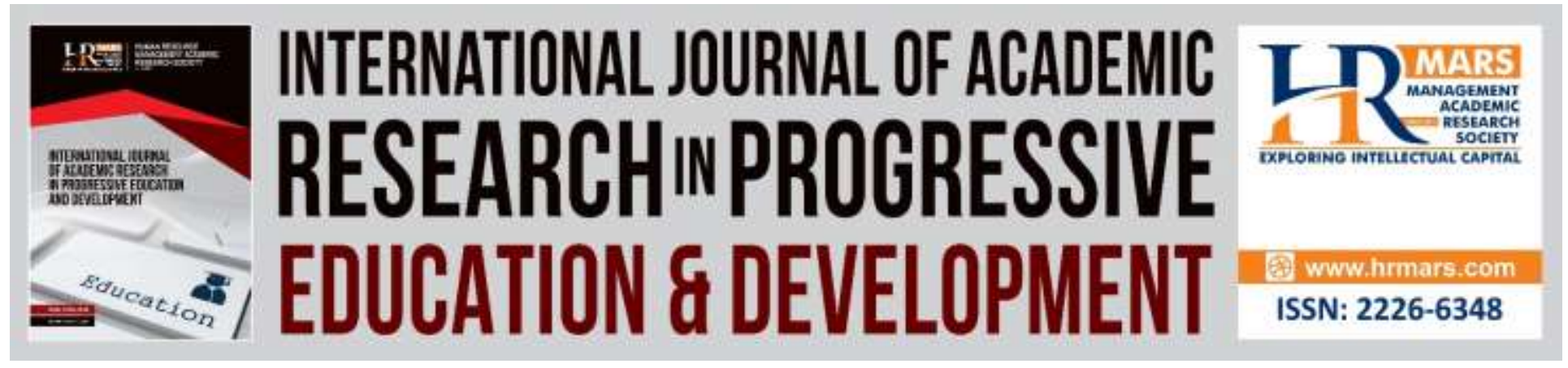

\title{
Promotion of Learner Autonomy: Beliefs and Practices from the ESL Teachers' Perspectives
}

Fauziah Ismail, Melor Md Yunus, Azizah Mohd Zahidi

To Link this Article: http://dx.doi.org/10.6007/IJARPED/v9-i2/7304

DOI:10.6007/IJARPED/v9-i2/7304

Received: 20 March 2020, Revised: 26 April 2020, Accepted: 18 May 2020

Published Online: 17 June 2020

In-Text Citation: (Ismail et al., 2020)

To Cite this Article: Ismail, F., Yunus, M. M., \& Zahidi, A. M. (2020). Promotion of Learner Autonomy: Beliefs and Practices from the ESL Teachers' Perspectives. International Journal of Academic Research in Progressive Education and Development, 9(2), 309-317.

Copyright: (C) 2020 The Author(s)

Published by Human Resource Management Academic Research Society (www.hrmars.com)

This article is published under the Creative Commons Attribution (CC BY 4.0) license. Anyone may reproduce, distribute, translate and create derivative works of this article (for both commercial and non-commercial purposes), subject to full attribution to the original publication and authors. The full terms of this license may be seen at: http://creativecommons.org/licences/by/4.0/legalcode

\section{Vol. 9(2) 2020, Pg. 309 - 317}

Full Terms \& Conditions of access and use can be found at http://hrmars.com/index.php/pages/detail/publication-ethics 


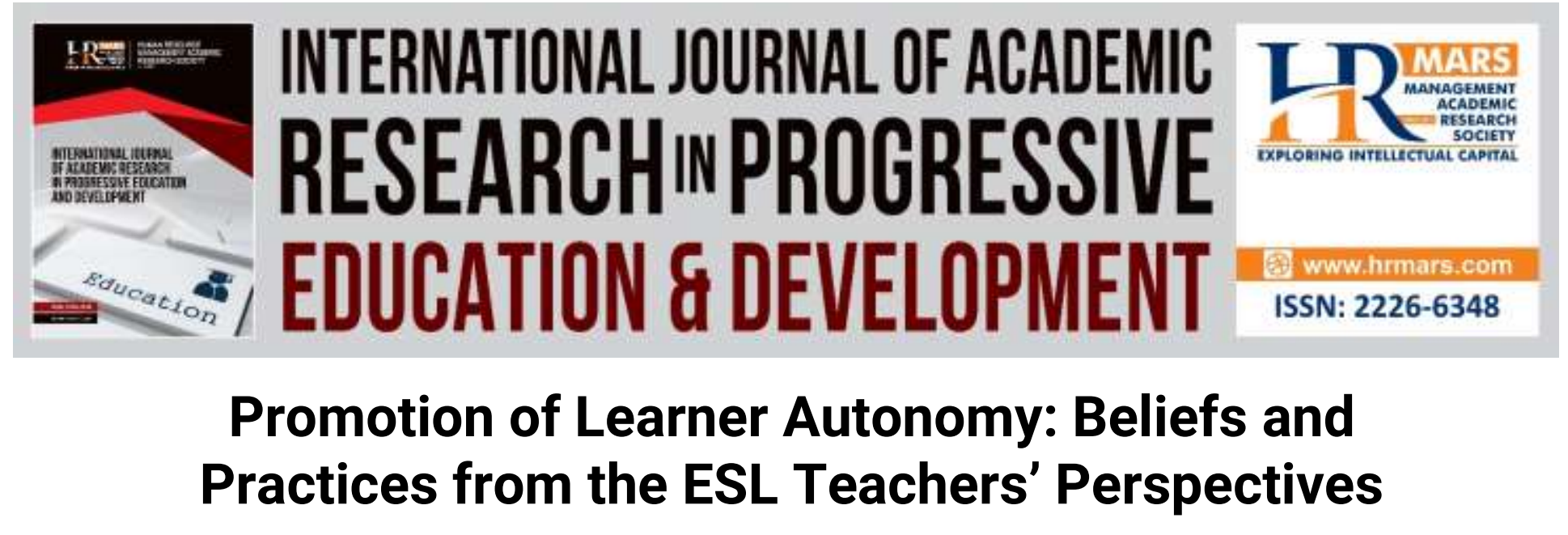

\author{
Fauziah Ismail, Melor Md Yunus, Azizah Mohd Zahidi \\ Universiti Kebangsaan Malaysia, Malaysia
}

\begin{abstract}
Belief influences practices. Ideally, the success of having autonomous language learning and autonomous learners is very much influenced by the teachers' beliefs about learner autonomy, which in most cases, will be manifested in their teaching practices. This paper reviews few studies concerning the beliefs and practices in promoting learner autonomy from the perspectives of English teachers in Asian context that followed the methodological pattern and the questionnaire developed by Borg and Busaidi (2012b). This paper discusses the findings of the reviewed studies in terms of the contexts and participants of the studies, the data collection used and the findings. The findings from nine Asian countries namely China, Japan, Cambodia, Philippines, Singapore, Brunei, Thailand, Indonesia and Malaysia have revealed that there are common similarities and various distinguished differences identified. With the overall findings that showed a mismatch between beliefs and practices of the ESL teachers participated in the studies reviewed, recommendations for future research is provided. To conclude, these studies have provided some insights and reference for future research on promotion of learner autonomy which enacted to teachers' beliefs.
\end{abstract}

Keywords: Learner Autonomy, Beliefs, Practices, ESL, ESL Teachers.

\title{
Introduction
}

Up to date, many studies on learner autonomy particularly in language learning pertaining its importance, beliefs, practices as well as the relationship with other variables and many more. The term learner autonomy is popularly described as the capability of the learners to take control of their own learning. The idea of autonomous language learning (ALL) is a shift or transition from teacher-centred to student-centred where the learner is fully involved in the learning process. However, it does not mean they are totally on their own. The learning is co-constructed where the teacher plays a vital role to facilitate the learners. As claimed by Benson (2007), the goal of learning is to create autonomous learners. With the emergence of $21^{\text {st }}$ century learning and $4^{\text {th }}$ Industrial Revolution, having autonomous learners seem to be ideal in order to have a meaningful and authentic learning which focuses on the learners' success not only in learning the language, but as well as in other subjects and aspects of life too. However, teachers' voices have not been 
explored in most studies, and little is actually known about to what degree learner autonomy means to ESL teachers and to what extent it is being implemented (Borg \& Busaidi, 2012).

Understanding teachers' beliefs about learner autonomy is a crucial element to further understand the practices of ESL teachers in promoting learner autonomy in ESL classroom. As defined by Borg (2006), teacher's belief is what teachers think, know and believe. In understanding teachers and teaching, Johnson (2006) described teacher cognition as the main area of interest in many studies which has made the most substantial contribution in the last 40 years. For the purpose of reviewing all these studies, two points are significant. First, teachers' beliefs can powerfully influence what teachers do and consequently, the learning opportunities the learners would receive. Therefore, the extent to and manner in which learner autonomy is promoted in language learning classrooms is influenced by the teachers' beliefs about what autonomy is, and what is desirable and feasible in certain contexts. Second, teachers' beliefs are more likely to have an effect on their practices when it is stemmed on the understanding of the beliefs teachers hold (Borg, 2011). Thus, this paper aims to review the current studies to further understand the beliefs and practices on learner autonomy from the ESL teachers' perspectives and the gaps that might exist.

\section{The Reviewed Studies}

The review based on nine studies that were carried out in various Asian contexts, which had replicated and followed similar methodological pattern established in Borg and Busaidi's (2012) study as indicated in Table 1. 
Vol. 9, No. 2, 2020, E-ISSN: 2226-6348 @ 2020 HRMARS

Table 1. Reviewed studies on teachers' beliefs and practices regarding learner autonomy in Asia (2016).

\begin{tabular}{|c|c|c|c|c|c|}
\hline Source & Country & Context & Participants & Methods & Findings \\
\hline $\begin{array}{l}\text { Nguyen } \\
(2012)\end{array}$ & Vietnam & University & Teachers & $\begin{array}{l}\text {-questionnaires } \\
\text {-interviews }\end{array}$ & $\begin{array}{l}\text { Value of LA is acknowledged but the } \\
\text { notion of giving learners' choice } \\
\text { was not prominent; teachers were } \\
\text { not confident in students' ability to } \\
\text { take control of their learning. }\end{array}$ \\
\hline $\begin{array}{l}\text { Wang \& Wang } \\
\text { (2016) }\end{array}$ & China & University & $\begin{array}{l}\text { English } \\
\text { teachers }\end{array}$ & $\begin{array}{l}\text {-questionnaires } \\
\text {-interviews } \\
\text {-workshops } \\
\text {-email } \\
\text { correspondence }\end{array}$ & $\begin{array}{l}\text { LA viewed as taking responsibility, } \\
\text { control and making decisions; } \\
\text { teachers' ideas about how to } \\
\text { promote LA are not as developed as } \\
\text { their theoretical understandings of } \\
\text { the concept; lack of student } \\
\text { motivation is a barrier. }\end{array}$ \\
\hline $\begin{array}{l}\text { Stroupe, Rundle } \\
\text { \& Tomita }\end{array}$ & e Japan & $\begin{array}{l}\text { Private } \\
\text { University }\end{array}$ & Teachers & $\begin{array}{l}\text {-questionnaires } \\
\text {-interviews } \\
\text {-workshops }\end{array}$ & $\begin{array}{l}\text { Positive attitudes to LA found; } \\
\text { curricular obstacles such as fixed } \\
\text { course goals identified. }\end{array}$ \\
\hline
\end{tabular}

Keuk \& Heng Cambodia University $\quad$ EL Teachers $\quad$-questionnaires Under 50\% of teachers agreed their
-email interviews students had a fair degree of -workshops autonomy; prescribed curricula and materials of teaching are seen to hinder LA.

\begin{tabular}{|c|c|c|c|c|c|}
\hline $\begin{array}{l}\text { Haji Othman } \\
\text { \& Wood }\end{array}$ & Brunei & $\begin{array}{l}\text { Secondary \& } \\
\text { Tertiary }\end{array}$ & Teachers & $\begin{array}{l}\text {-questionnaires } \\
\text {-workshops }\end{array}$ & $\begin{array}{l}\text { Positive idealistic views on LA } \\
\text { contrasted with practical }\end{array}$ \\
\hline & & Institutions & & $\begin{array}{l}\text {-focus } \text { group } \\
\text { interview }\end{array}$ & implementatic \\
\hline Tapinta & Thailand & University & Teachers & $\begin{array}{l}\text {-questionnaires - } \\
\text { email interviews } \\
\text {-workshops }\end{array}$ & $\begin{array}{l}\text { Positive attitudes to LA; students } \\
\text { are lacked of awareness and skills } \\
\text { for LA; contextual constraints } \\
\text { limited promotion of LA in teaching. }\end{array}$ \\
\hline
\end{tabular}

\begin{tabular}{|c|c|c|c|c|c|}
\hline $\begin{array}{l}\text { Ranosa, Madrino, } \\
\text { Tarrayo, Tupas \& } \\
\text { Valdez }\end{array}$ & Philippines & $\begin{array}{l}\text { Urban } \\
\text { University }\end{array}$ & $\begin{array}{l}\text { English } \\
\text { Instructors }\end{array}$ & $\begin{array}{l}\text {-questionnaires } \\
\text {-interviews } \\
\text {-workshops }\end{array}$ & $\begin{array}{l}\text { LA is seen to be both desirable in } \\
\text { theory and feasible in practice. } \\
\text { Students are seen to be fairly } \\
\text { autonomous. Prescribed curricula } \\
\text { and lack of training for staff work } \\
\text { against LA. }\end{array}$ \\
\hline Lengkanawati & Indonesia & $\begin{array}{l}\text { Secondary } \\
\text { and Tertiary } \\
\text { Institutions }\end{array}$ & Teachers & $\begin{array}{l}\text {-questionnaires } \\
\text {-focus group } \\
\text { interview } \\
\text {-workshops }\end{array}$ & $\begin{array}{l}\text { Positive attitudes to LA are found } \\
\text { but secondary school students } \\
\text { seem to need teachers' guidance in } \\
\text { making decisions about their } \\
\text { learning. }\end{array}$ \\
\hline Hasim \& Zakaria & Malaysia & $\begin{array}{l}\text { Secondary } \\
\text { School }\end{array}$ & Teachers & $\begin{array}{l}\text {-questionnaires } \\
\text {-interviews }\end{array}$ & $\begin{array}{l}\text { Positive attitudes to LA and } \\
\text { awareness of the concept though } \\
\text { some were not sure of the concept. }\end{array}$ \\
\hline
\end{tabular}

\section{Discussion}

In reviewing all these studies done in Asian context, the discussion will be on common similarities and distinguished differences in terms of contexts and participants, data collection and findings. The nine studies are from Vietnam, China, Japan, Cambodia, Brunei, Thailand, Philippines, Indonesia and Malaysia. 
INTERNATIONAL JOURNAL OF ACADEMIC RESEARCH IN PROGRESSIVE EDUCATION AND

DEVELOPMENT

Vol. 9, No. 2, 2020, E-ISSN: 2226-6348 @ 2020 HRMARS

\section{Context and Participants}

The review among nine studies as illustrated in Table 1 found that the participants are all English language teachers; from two different educational settings. The participants in Nguyen's, Wang and Wang's, Stroupe, Rundle and Tomita's, Keuk and Heng's, Tapinta's, Ranosa, Madrino, Tarrayo, Tupas and Valdez's (2016) studies exploring the beliefs and practices of learner autonomy from the teachers' perspectives in the university context. Meanwhile, the studies from Othman and Wood, Lengkanawati and Hasim and Zakaria investigated the beliefs and practices of learner autonomy from the context of secondary and tertiary institutions and primary and secondary schools. This suggests that the instruments adapted from Borg and Busaidi (2012b) is valid and reliable through these nine studies pertaining to beliefs and practices of ESL teachers and lecturers.

\section{The Instruments Used}

The instruments used in all nine studies reviewed in this paper are questionnaires, interviews and workshops held for professional development adapted from Borg and Busaidi (2012). It was developed for the purpose of investigating the beliefs and practices regarding learner autonomy of the participants, who are English language teachers. Among the instruments used, the questionnaire by Borg and Busaidi (2012b) has currently being adapted and adopted by many studies in relation to learner autonomy. It has emerged as a clear and useful instrument for researchers who are working on learner autonomy specifically on beliefs and practices from the teachers' perspectives. The questionnaire consisted of five sections, with 5-Likert scale options, as well as open-ended questions. The questionnaire is used in all studies as the main data collection.

Besides the survey questionnaire, interviews and workshops held for professional development were also conducted in most studies. The interview, which consisted eight leading questions adapted from Borg and Busaidi (2012b) were used to elicit the participants' information on their perceptions and practices regarding learner autonomy as reported in the initial survey. The interviews and workshops were conducted by the researchers according to the contexts of their studies. The workshops were then, held up based on the reported findings in the survey and interviews conducted initially.

Even though almost all the studies followed the methodological patterns of Borg and Busaidi (2012b), there are some considerable variations depending on the contexts of their studies. The data collection across nine studies showed that most of the studies employed multiple tools for data collection. The most frequently used instruments were the questionnaires, interviews and workshops conducted as in Wang Wang's, Stroupe, Rundle and Tomita's, Tapinta's, Ranosa, Madrino, Tarrayo, Tupas and Valdez's and Keuk and Heng's studies. Due to some constraints, Keuk and Heng conducted the interview via email. On the other hand, Nguyen and Hasim and Zakaria collected the data through survey and interviews while Lengkanawati collected her data through survey and workshops conducted. However, Othman and Woods' study was the only study that used survey as the tool for data collection. 
Vol. 9, No. 2, 2020, E-ISSN: $2226-6348$ @ 2020 HRMARS

The questionnaire was used in all reviewed studies as the main instrument to collect data on the participants' beliefs and their self-report practices on learner autonomy. In general, seven studies applied all the three data collection accordingly namely survey, interviews and workshops conducted. However, one study which was by Stroupe, Rundle and Tomita (2016) did not follow the pattern, as they conducted the workshop prior to the interview. As for the workshops, some studies would have two up to four workshops held depending on the feasibility in each study. The number of researchers involved in the studies were also varied either single or on collaborative efforts.

Overall, the application of Borg and Busaidi's methodological approach in most of the reviewed studies across various Asian countries has proven enormously valuable to gain more insights on the participants' perceptions and reported practices regarding learner autonomy. The findings from the questionnaires, interviews as well as subsequent workshops have provided better understanding of the variables measured; teachers' beliefs and their reported practices.

\section{Findings}

The review of nine studies in Asian context has yielded an insights into at least three areas; beliefs, practices and constraints. In terms of beliefs, the findings in all studies indicated that majority of the participants showed their initial understanding of LA from the questionnaire responses. Most of the participants have fair understanding, high beliefs and positive disposition towards learner autonomy. This indicated that the ESL teachers in all the studies reviewed are aware of the concept.

In terms of practices, there are cases of mismatch or incongruence between beliefs and practices due to educational, contextual and cultural constraints. Most studies have shown different results according to their specific contexts. In general, most ESL teachers claimed they have promoted learner autonomy in their teaching practices though there are limitations and constraints. The limitations can be either from the ESL teachers themselves or their learners. As for the ESL teachers, they claimed that they are unsure of the concept, lacked of confidence, skills and training to manifest their beliefs on learner autonomy into practices. While learner-related limitations that hinder their practices are their students' lacking of readiness, motivation, understanding, awareness and guidance from teachers. These limitations as identified from the studies reviewed revealed that learner autonomy is a shared responsibility. Both teachers and learners need to work hand in hand to have autonomous language learning classroom. It will not work either way. This means, the capability to be autonomous needs to be trained to the learners too and the teachers will assist and guide them to facilitate the learning process. The findings from these studies reviewed confirm that the theory of Social Constructivism, Zone of Proximal Development and scaffolding are still relevant to the current practice in promoting learner autonomy.

In conclusion, the findings from all the studies reviewed in this paper revealed that beliefs and practices in promoting learner autonomy from the teachers' perspectives have provided us with better understanding of what may contribute to the mismatch of these two variables; 
teachers' beliefs and practices. The summary of findings for the reviewed studies is as illustrated in Figure 1 below.

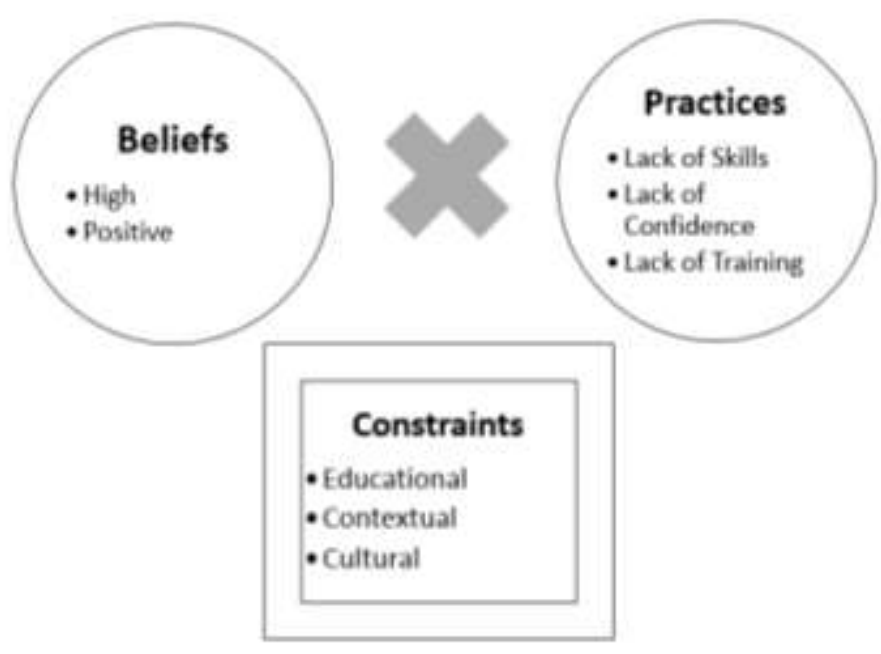

\section{Figure 1. Summary of findings of the reviewed studies on teachers' beliefs and practices regarding learner autonomy in Asia.}

\section{Recommendations}

Based on the reviewed studies done in Asian contexts, it can be concluded that there are mismatch and inconsistencies between teachers' beliefs and practices. These could be due to few contributing factors that lead to the discrepancies such as contextual and cultural constraints as mentioned in few studies. Therefore, future research might need to investigate how diversities in teachers with different personal backgrounds, and in different contexts will respond to each of the suggested factors. Perhaps, the results from such studies might give some ideas for solution to the discrepancies between beliefs and practices. Further studies should consider the constraints that had existed prior the studies conducted.

Secondly, future studies are recommended to investigate not only the beliefs and practices of English teachers but also their language learners. This is because, as agreed by many scholars in the literature, successful language learners are those of autonomous learners. To have an autonomous language learning ( $A L L)$, it starts from the teacher. Teachers with a repertoire teaching styles, approaches and strategies would facilitate language learners to become autonomous. Such research would allow us to reflect the impact of the teachers' classroom practices on their students' behavior (Zhou, Ma \& Deci, 2009; Black \& Deci, 2000).

Finally, further studies could consider observation as a tool for data collection to gain more insights on the practices of the teachers in promoting learner autonomy in the classroom. This is very much important as observation will allow us to explore more dimensions of the practices in the classroom setting, in their own specific contexts, especially the approaches and strategies used in developing or promoting learner autonomy as well as the feasibility of 
implementing LA in the classroom. The findings from the observation would further provide better understanding of the initial findings obtained from the questionnaires and interviews.

\section{Conclusion}

The nine studies reviewed from Asian countries have provided evidence on beliefs and practices regarding learner autonomy from the teachers' perspectives. Ideal autonomous learners play important roles in their own learning process by taking control of their own learning and make most decisions on their learning. However, learner autonomy is very much likely depends on the teacher autonomy as these both go hand in hand. Learner autonomy is a shared responsibility. The support that the learners receive from their teachers and the opportunities given are based on the teachers' beliefs on learner autonomy, hence implemented through the practices in the classroom. Both teachers and learners will benefit from teachers who have high beliefs and understanding of the concept of learner autonomy.

This highlights the important roles the teachers have in students' transformation to be autonomous learners. Despite of the constraints existed in some contexts in the studies reviewed, more insights were gained especially to what degree LA is understood and to what extent it is being implemented. Further studies should consider the insightful findings gained from these studies reviewed. The foremost findings from the reviewed studies is that the feasibility of promoting learner autonomy depends on the extent to which beliefs on learner autonomy is held by the teachers, and the pedagogical principles that are understood, accepted and rooted in the language classes. It is hoped that more research in the future will come up with more critical theoretical as well as practical views to explore the extent that learner autonomy is conceptualized in the recent trend in teaching and learning of English as a second language.

\section{Corresponding Author}

Fauziah Ismail is currently a PhD student at Faculty of Education, Universiti Kebangsaan Malaysia. She has been a lecturer, teaching English at Institut Pendidikan Guru Kampus Pendidikan Islam, Selangor since 2008. Her main research interests include learner autonomy and teacher training.

\section{References}

Benson, P. (2001). Teaching and researching autonomy in language learning. Harlow: Longman. Benson, P. (2011) Teaching and Researching Autonomy in Language Learning. 2nd Edition Harlow: Longman/Pearson Education.

Benson, P. (2007). Autonomy in language teaching and learning. State of the art article. Language Teaching, 40: 21-40.

Benson, P. (2013). Teaching and researching autonomy (2nd ed.). New York: Routledge

Borg, S., \& Al-Busaidi, S. (2012). Learner Autonomy: English Language Teachers' Beliefs and Practices. London: British Council.

Dickinson, L. (1995). Autonomy and motivation. A literature review. System, 23(2), 165-174.

Holec, H. (1981). Autonomy and foreign language learning. Oxford: Pergamon

Little, D., Ridley, J., \& Ushioda, E. (Eds.). (2003). Learner autonomy in the foreign language classroom: Teacher, learner, curriculum and assessment. Dublin: Authentik. 
INTERNATIONAL JOURNAL OF ACADEMIC RESEARCH IN PROGRESSIVE EDUCATION AND DEVELOPMENT

Vol. 9, No. 2, 2020, E-ISSN: 2226-6348 @ 2020 HRMARS

Littlewood, W. (1999). Defining and developing autonomy in East Asian contexts. Applied Linguistics, 20(1), 71-94

Haji-Othman, N. A., \& Wood, K. (2016). Perceptions of learner autonomy in English language education in Brunei darussalam. In: R. Barnard, \& J. Li (Eds.), Language learner autonomy: Teachers' beliefs and practices in Asian contexts (pp. 79-95). Phnom Penh: IDP Education.

Hasim, Z., \& Zakaria, A. R. (2016). ESL Teachers' knowledge on learner autonomy. In Knowledge, Service, Tourism \& Hospitality: Proceedings of the Annual International Conference on Management and Technology in Knowledge, Service, Tourism \& Hospitality 2015 (SERVE 2015). CRC Press

Keuk, C. N., \& Heng, V. (2016). Cambodian ELT teachers' beliefs and practices regarding language learner autonomy. In: R. Barnard, \& J. Li (Eds.), Language learner autonomy: Teachers' beliefs and practices in Asian contexts (pp. 62-78). Phnom Penh: IDP Education.

Lengkanawati, N. S. (2016). Teachers' beliefs about learner autonomy and its implementation in Indonesian EFL settings. In: R. Barnard, \& J. Li (Eds.), Language learner autonomy: Teachers' beliefs and practices in Asian contexts (pp. 134-149). Phnom Penh: IDP Education.

Nguyen, V. L. (2016). Learner autonomy in Vietnam: Insights from English language teachers' beliefs and practices. In: R. Barnard, \& J. Li (Eds.), Language learner autonomy: Teachers' beliefs and practices in Asian contexts (pp. 1-22). Phnom Penh: IDP Education.

Ranosa-Madrunio, M., Tarrayo, V. N., Tupas, R., \& Valdez, P. N. (2016). Learner autonomy: English language teachers' beliefs and practices in the Philippines. In: R. Barnard, \& J. Li (Eds.), Language learner autonomy: Teachers' beliefs and practices in Asian contexts (pp. 114-133). Phnom Penh: IDP Education.

Stroupe, R., Rundle, C., \& Tomita, K. (2016). Developing autonomous learners in Japan: Working with teachers through professional development. In R. Barnard, \& J. Li (Eds.), Language learner autonomy: Teachers' beliefs and practices in Asian contexts (pp. 43-61). Phnom Penh: IDP Education.

Tapinta, P. (2016). Thai teachers' beliefs in developing learner autonomy: L2 education in Thai universities. In R. Barnard, \& J. Li (Eds.), Language learner autonomy: Teachers' beliefs and practices in Asian contexts (pp. 96-113). Phnom Penh: IDP Education.

Wang, Y., \& Wang, M. (2016). Developing learner autonomy: Chinese university EFL teachers' perceptions and practices. In R. Barnard, \& J. Li (Eds.), Language learner autonomy: Teachers' beliefs and practices in Asian contexts (pp. 23-42). Phnom Penh: IDP Education.

Zhou, M., Ma, W. J., \& Deci, E. L. (2009). The importance of autonomy for rural Chinese children's motivation for learning. Learning and Individual Differences, 19(4), 492-498. 